\title{
Meperidine: opioid not indicated for analgesia*
}

\author{
Meperidina: opioide não indicado para analgesia
}

\author{
Andresa Graciutti Botan, Simone Aparecida Biazzi de Lapena \\ ${ }^{*}$ Received from Paulista University, São José dos Campos, SP, Brazil.
}

\section{ABSTRACT}

BACKGROUND AND OBJECTIVES: Pain evaluation and the choice of the analgesic best providing its control are extremely important for patients' quality of life. This study aimed at describing the characteristics which make meperidine unfeasible for pain management, at calling the attention to the incidence of its prescriptions and to the need of a multidisciplinary educative action aiming at decreasing its use, in addition to presenting two opioids as options for analgesia.

CONTENTS: National or international scientific and governmental publications between the years 1997 and 2013 used in this study report that meperidine is not indicated for pain management, primarily due to its short action time, presence of neurotoxic metabolite (normeperidine) and possibility of rapidly developing tolerance.

CONCLUSION: According to analyzed data, meperidine was the most widely used opioid for analgesic or was among the most prescribed analgesics. This fact shows the real need for an educative multidisciplinary action to promote awareness of meperidine risks and to decrease its prescription. According to searched literature, morphine and methadone have longer action time and higher analgesic potency, with metabolites which are less toxic and noxious for patients as compared to meperidine.

Keywords: Analgesia, Meperidine, Methadone, Morphine, Pain.

\section{RESUMO}

JUSTIFICATIVA E OBJETIVOS: A avaliação da dor e a escolha do analgésico que mais bem provenha o seu controle são de extrema importância para a qualidade de vida do paciente. $\mathrm{O}$ objetivo deste estudo foi elucidar as características que inviabilizam a administração da meperidina para o tratamento da dor, atentar para a incidência de sua prescrição e a necessidade de uma

1. Paulista University, São José dos Campos, SP, Brazil.

Submitted in May 13, 2014.

Accepted for publication in January 18, 2015.

Conflict of interests: none - Sponsoring sources: none.

Correspondence to:

Andresa Graciutti Botan

Rua Professora Aurora Paes da Costa, 65 - Vila Antônio Augusto

12287-220 Caçapava, SP, Brasil.

E-mail: desa_gb_@hotmail.com

(c) Sociedade Brasileira para o Estudo da Dor açáo educativa multidisciplinar visando à redução do seu uso e apresentar dois opioides como opçóes de escolha para a analgesia. CONTEÚDO: As publicaçóes científicas e governamentais de âmbito nacional ou internacional entre os anos de 1997 e 2013 utilizadas neste artigo relatam que a meperidina náo é indicada para o tratamento da dor devido, principalmente, ao seu curto tempo de ação, presença de metabólito neurotóxico (normeperidina), e a possibilidade de desenvolver tolerância rapidamente.

CONCLUSÁO: Segundo os dados das pesquisas analisadas, a meperidina foi o opioide mais utilizado para analgesia ou estava entre os analgésicos mais prescritos. Esse fato relata a real necessidade de uma açáo multidisciplinar educativa em prol da conscientização sobre os riscos presentes no tratamento com a meperidina e da diminuição da sua prescrição. De acordo com a literatura consultada, a morfina e a metadona apresentam maior tempo de ação e potência analgésica com metabólitos menos tóxicos e prejudiciais ao paciente que a meperidina.

Descritores: Analgesia, Dor, Meperidina, Metadona, Morfina.

\section{INTRODUCTION}

Pain is defined as sensory, emotional, subjective, personal and unpleasant experience related to real or potential tissue injury ${ }^{1}$.

Pain evaluation is critical for its adequate control, since several studies have shown that non-relieved pain limits individuals in their daily activities, changes mood, exacerbates pain fear, thus affecting the quality of life (QL) of patients and their caregivers ${ }^{2}$.

The World Health Organization (WHO) recommends strong opioids to manage acute or severe chronic pain, associated or not to non-opioids, adjuvants or non-pharmacological techniques, aiming at improving pain and $\mathrm{QL}^{1,3}$.

Meperidine is a strong opioid, however due to some unique features WHO itself and the authors of national and international articles or governmental publications published between 1997 and 2013 and searched in this study, report the non-recommendation of its use for analgesia and suggest its replacement by other opioids.

This study aimed at defining the features which make meperidine unfeasible for pain management, at calling the attention for the incidence of its prescription and the importance of a multidisciplinary educative action to decrease its use, since there is the option of other strong opioids with less toxicity, in addition to introducing morphine and methadone as options for analgesia. 


\section{CONTENTS}

Meperidine (or petidine) is a synthetic opioid which, for being structurally similar to morphine, atropine, cocaine and histamine, has several pharmacological effects, such as analgesic, spasmolytic, general anesthesia and mild anti-histaminic activity ${ }^{4}$.

It acts by binding to $\mathrm{Mu}(\mu)$ and Kappa $(\kappa)$ opioid receptors ${ }^{5}$, being 10 times less potent than morphine ${ }^{6}$.

Meperidine administration route is primarily intramuscular, but it is also well absorbed in the gastrointestinal tract; its action lasts from two to four hours being biotransformed in the liver where, by the N-demethylation process, forms its primary metabolite, normeperidine (or norpetidine), and is excreted by the urine ${ }^{5}$.

Normeperidine half-life is between 14 and $21 \mathrm{~h}$, it has twice more stimulating effects which potentially toxic in the central nervous system (CNS) and has just half the analgesic properties of meperidine ${ }^{1,3}$.

After meperidine administration, due to its short action time, painful sensation reappears and a new dose is necessary, however normeperidine produced as from the first dose will add to that of the second dose, and so on. By the cumulative effect and due to its long plasma half-life, this metabolite may reach dangerously toxic levels ${ }^{7}$.

Prolonged administration results in normeperidine buildup, which is hepatotoxic ${ }^{8}$, and acts stimulating the CNS generating myoclonus, delirium, more severe psychomotor agitation and seizures ${ }^{1,7}$.

There may be meperidine metabolites buildup in patients with kidney or liver failure ${ }^{1}$.

Among major reasons for using meperidine there are its easy availability, short action time, for not inducing miosis ${ }^{9}$ and also due to the belief that such short-action opioid will cause less dependence ${ }^{10}$.

Physical dependence and withdrawal symptoms are as severe as those of morphine ${ }^{11}$. However, in early dependence, reports that after just some few doses there is already an imperious will of not living without this opioid, together with more severe intoxication symptoms, make meperidine a more hazardous drug for the development of tolerance and addiction $^{1,11,12}$.

Garcia \& Santos ${ }^{11}$ report that several authors mention the drug addiction potential with the use of meperidine and mention a study evaluating hospital admission cases due to dependence, which had the following results: 457 admittedly meperidine addicted individuals, of whom 288 have become dependent after contact with this opioid without previous use of any other substance.

For acute pain management, when morphine muscarinic effects are not desirable, meperidine may erroneously be the drug of choice ${ }^{7}$. Some authors advocate meperidine as the best solution to control shivering at the end of surgical and anesthetic procedures, however, this shivering may be prophylactically prevented by directly warming part of the body and the surgical bed with thermal mattresses and blankets and by maintain- ing operating room temperature between $21^{\circ}$ and $24^{\circ} \mathrm{C}^{7}$. During the 1980s, the follow-up of meperidine complications has recommended lower total daily dose, especially in situations where repeated doses were prescribed, and since in following years science was unable to establish safe levels for this opioid, not even for young adults with normal kidney functions, several authors started to advocate the non-prescription of meperidine ${ }^{7}$.

The International Association for the Study of Pain (IASP), the WHO and other entities recommend restricted use of meperidine to manage acute pain and its replacement, whenever possible, by other less toxic opioids; and strongly condemn its use to manage chronic pain, which in addition to toxicity may also induce chemical dependence because the development of tolerance to meperidine is very fast and may appear even with a single dose $\mathrm{e}^{1,7}$.

However, this restriction or replacement seems not to be occurring because available studies report excessive meperidine consumption in Brazilian and other developing countries hospitals ${ }^{3}$.

A study ${ }^{13}$ has observed meperidine and morphine prescription profile in a hospital and has concluded that the most frequently used opioid was meperidine, being present in $90 \%$ of evaluated prescriptions, especially to manage postoperative pain.

According to data of the II Home Survey on the use of Psychotropic Drugs in Brazil in 2005, meperidine was the second most used opioid reported by respondents ${ }^{11}$.

According to Moura, Ribeiro \& Magalhães report ${ }^{15}$, meperidine is among the 10 most prescribed opioids in the studied hospital.

In the study by Calil \& Pimenta ${ }^{16}$, addressing relationships between analgesic pattern and trauma severity, meperidine was the most prescribed opioid, being present in $10.4 \%$ of all analgesic prescriptions.

A study ${ }^{17}$ has observed pain incidence in cosmetic surgeries and analgesia and has concluded that the most prescribed analgesic was meperidine.

In their studies, Souza $\&$ Alves Neto ${ }^{18}$ have evaluated physicians' knowledge about pain management and their analgesic approaches and have shown that a high percentage of physicians $(29.57 \%)$ used meperidine.

A study ${ }^{19}$ aiming at understanding nurses perception about opioid administration for non-malignant chronic pain relief has observed that a relevant number of nurses $(26.7 \%)$ has mentioned meperidine as an opioid to relief such pain.

Among currently used opioids for labor analgesia, meperidine is the most widely used and studied ${ }^{20,21}$. In most studies, meperidine shows a certain level of analgesia, however in a large number of cases it has insufficient response, leading some authors to suggest that it acts much more as sedative than as analgesic $^{21}$. There is also a report of adverse effects, such as mother nausea, vomiting and dizziness or neonate respiratory depression $^{20-22}$.

In addition to delivery, one should also pay attention to breastfeeding, because since meperidine has a long half-life 
active metabolite, the dose excreted in the milk may buildup in the infant causing behavioral depression, difficulty to suck breast milk or seizure ${ }^{23,24}$.

According to a study ${ }^{23}$, meperidine may be replaced by morphine as post-delivery analgesic, because morphine has a higher analgesic power and induces less sedation. In addition, the concentration of its metabolite in the milk is considered compatible with breastfeeding.

The percentage of meperidine prescription as compared to the prescription of other opioids during hospital stay is used as hospital quality standard and accreditation in developed countries, being accepted up to $20 \%$ of meperidine prescription among total opioids in emergency settings, and up to $10 \%$ for hospitalization sectors, being that in institutions where these percentages are exceeded, physicians receive therapeutic update courses with emphasis meperidine ${ }^{7}$.

The implementation of the educational multidisciplinary protocol to decrease meperidine prescription in the Israelite Hospital Albert Einstein was effective because it has significantly contributed to decrease its consumption ${ }^{3}$.

In 2006, the Ministry of Health has recommended the exclusion of meperidine from the National List of Essential Drugs (RENAME) due to the presence of the neurotoxic metabolite normeperidine, its short action time and for being three times more expensive than morphine without having therapeutic advantages ${ }^{25}$

Morphine acts as exogenous agonist of $\mathrm{Mu}(\mu)$, Kappa ( $\kappa)$ and Delta $(\delta)$ opioid receptors, being considered the standard of all central action analgesics and used to manage severe chronic and acute pain ${ }^{1,5,26,27}$.

Morphine has action duration of four to six hours, half-life of three to four hours, being biotransformed in the liver and originating metabolites: morphine-3-glucorunide and morphine-6-glucorunide ${ }^{5,28}$.

Morphine-3-glucorunide is considered inactive due to poor affinity with opioid receptors ${ }^{1}$. Morphine-6-glucorunide is considered active with plasma half-life of two hours, being a potent $\mu$ receptors agonist, which may contribute to morphine analgesic effect ${ }^{1,29}$.

There may be morphine metabolites buildup in patients with kidney failure ${ }^{27}$.

Oral morphine is less potent than injectable morphine because the absorption is fast and incomplete, being soon metabolized and obtaining approximately $1 / 5$ to $1 / 3$ of plasma concentration reached by injectable parenteral route, so infusion pumps or scheduled release capsules may be used aiming at patients' wellbeing ${ }^{1,30,31}$.

Plummer et al. ${ }^{32}$ results have indicated that morphine was more effective to control postoperative pain as compared to meperidine.

In a systematic review, most authors use morphine as first line opioid and methadone as second option ${ }^{33}$.

Methadone is a synthetic opioid agonist of Mu, Delta and Kappa opioid receptors and antagonist of N-methyl-D-aspartate (NMDA) receptors. It was initially used to prevent and control opioid withdrawal syndrome, which has stigmatized it, creating a certain resistance to its use as analgesic ${ }^{1,26}$.

Oral methadone absorption is fast and almost complete ${ }^{26}$. Its analgesic effect, with is five to ten times higher than morphine, in general lasts for six to eight hours ${ }^{26}$.

Primary methadone metabolites, "EDDP" (2-ethylene-1,5 dimethyl 3-3 diphenylpyrrolidine) and "EMDP" (2 ethyl 5 methyl 3-3 diphenyl pyrroline) are inactive and excreted especially by feces, and urine, being that renal excretion decreases along time allowing its use in patients with chronic kidney disease $e^{26,34}$.

Methadone should be carefully prescribed due to its long plasma half-life of 13 to 50h, needing frequent follow up and gradual dose evolution, if needed, until the effective dose is found ${ }^{1}$. Methadone induces less nausea, constipation and sedation as compared to morphine and its euphorizing effect and psychic and physical dependence rates are lower as compared to other opioids $^{26}$.

Salamonde et al..$^{35}$ have observed patient controlled analgesia at home with methadone and have concluded that this opioid is a safe and effective option, not inducing significant side effects. Ribeiro, Schmidt \& Schmidt ${ }^{26}$ have reported that methadone may be an option to treat chronic pain, especially in the presence of neuropathic pain, due to antagonism on NMDA receptor. In this study ${ }^{26}$, authors have also stated that methadone is effective and safe to treat cancer-related painful syndromes.

Table 1 was structured based on researched information and shows meperidine features which make unfeasible its use to manage pain, and helps the relationship and comparison with the options of studied opioids: morphine and methadone.

Table 1. Comparison among meperidine, morphine and methadone

\begin{tabular}{|c|c|c|c|}
\hline & Meperidine & Morphine & Methadone \\
\hline Action time & 2 to 4 hours & 4 to 6 hours & 6 to 8 hours \\
\hline $\begin{array}{l}\text { Analgesic } \\
\text { potency }\end{array}$ & $\begin{array}{l}10 \text { times lower } \\
\text { than morphine }\end{array}$ & $\begin{array}{l}\text { Comparison stan- } \\
\text { dard }\end{array}$ & $\begin{array}{l}5 \text { to } 10 \text { times } \\
\text { higher than } \\
\text { morphine }\end{array}$ \\
\hline \multirow{2}{*}{$\begin{array}{l}\text { Features of } \\
\text { major me- } \\
\text { tabolites }\end{array}$} & \multirow{2}{*}{$\begin{array}{l}\text { Normeperidine: } \\
\text { Hep a to toxic } \\
\text { and neurotoxic, } \\
\text { with half-life of } \\
14 \text { to } 21 \text { hours. }\end{array}$} & $\begin{array}{l}\text { Morphine-3-glu- } \\
\text { coronide: inactive }\end{array}$ & \multirow{2}{*}{$\begin{array}{l}\text { EDDP and } \\
\text { EMDP: } \\
\text { Inactive }\end{array}$} \\
\hline & & $\begin{array}{l}\text { Morphine-6-gluco- } \\
\text { ronide: Um recep- } \\
\text { tor agonist, contri- } \\
\text { buting to analge- } \\
\text { sia, with half-life of } \\
2 \text { hours. }\end{array}$ & \\
\hline
\end{tabular}

EDDP $=$ 2-ethylene-1,5 dimethyl 3-3 diphenylpyrrolidine; EMDP $=2$ ethyl 5 methyl 3-3 diphenyl pyrroline; NMDA: N-methyl-D-aspartate.

\section{CONCLUSION}

It was observed that meperidine is not indicated to manage pain; however, according to data of analyzed studies, it was the most widely prescribed opioid, or was among the most indicated or used analgesics. This fact calls the attention to the need of a multidisciplinary education of pharmacists, physicians and nurses, aiming at the awareness of the risks of meperidine use and at decreasing its prescription, limiting its administration to cases where other options were not effective of feasible. 
Morphine and methadone were introduced as alternatives for analgesia. Both opioids, according to data of researched literature, have longer action time and more analgesic potency with less toxic and noxious metabolites as compared to meperidine, allowing a more effective pain management and better quality of life.

\section{REFERENCES}

1. II Consenso Nacional de Dor Oncológica. 1ª ed. São Paulo: Moreira Junior; 2011. 176p.

2. da Silva YB, Pimenta CA. [Analysis of nursing registries of pain and analgesia in hospitalized patients]. Rev Esc Enferm USP. 2003;37(2):109-18. Portuguese.

3. Minson FP, Sardá Júnior J, Ferracini FT, Lopes AC, Fernandes Júnior CJ. [Decreased use of petidine in a private hospital with the implementation of a multiprofessional educative program]. Rev Dor. 2011;12(1):35-8. Portuguese.

4. Korolkovas A, Burckhalter JH. Química farmacêutica. Rio de Janeiro: Guanabara Koogan; 2008. 783p.

5. Howland RD, Mycek MJ. Farmacologia ilustrada. $3^{\text {a }}$ ed. Porto Alegre: Artmed; 2007. $551 \mathrm{p}$.

6. Pardos PC, Martínez IG. Utilidad de la meperidina en anestesiología. Rev Esp Anestesiol Reanim. 2000;47(4):168-76.

7. Oliveira Júnior JO. Meperidina: uma droga aguardando merecida jubilaçăo. 2009. Disponível em: <http://www.dor.org.br/news/02072009/meridinacompleto.pdf>.

8. Ferreira DT, Faccione M. Opiáceos, opioides de açăo analgésica e antagonistas. Semina: Ciências Exatas e Tecnológicas. 2005;26(2):125-36.

9. Latta KS, Ginsberg B, Barkin RL. Meperidine: a critical review. Am J Ther. 2002;9(1):53-68.

10. Kopf A, Patel NB. Guia para o tratamento da dor em contextos de poucos recursos. USA: IASP Press; 2010. 401p.

11. Garcia JBS, Santos CEC. Meperidina. In: Cavalcanti IL, Cantinho FAF, Vinagre RCO. Anestesia Venosa. Rio de Janeiro: Sociedade de Anestesiologia do Estado do Rio de Janeiro (SAERJ); 2004. 143-59p.

12. Lemonica L. Bases farmacológicas para uso clinico dos opióides. Prática Hospitalar. 2008;56:129-35.

13. Daudt AW, Hadlich E, Facin MA, Aprato RM, Pereira RP. [Opiates in pain management: correct or underestimated use? Data from a university hospital]. Rev Ass Med Brasil. 1998;44(2):106-10. Portuguese.

14. OBID. Observatório Brasileiro de Informaçóes sobre Drogas. II Levantamento Domiciliar sobre o uso de Drogas Psicotrópicas no Brasil 2005. Analgésicos Opiáceos. 2005. Disponível em: < http://www.obid.senad.gov.br/portais/OBID/biblioteca/documentos/Dados_Estatisticos/populacao_brasileira/II_levantamento_nacional/Substancia/326834.pdf>.

15. Moura CS, Ribeiro AQ, Magalhães SM. Avaliação de interaçóes medicamentosas potenciais em prescriçóes médicas do Hospital das Clínicas da Universidade Federal de Minas Gerais (Brasil). Rev Lat Am J Pharm. 2007;26(4):596-601.

16. Calil AM, Pimenta CA. [Relationship between trauma severity and analgesia standards used in traffic accident victims]. Rev Esc Enferm USP. 2009;43(2):328-34. Portuguese.
17. da Silva AP, Moraes MW. [Incidence of postoperative pain after aesthetic plastic surgery]. Rev Dor. 2010;11(2):136-9. Portuguese.

18. de Sousa CF, Alves Neto O. Perfil do manuseio da dor no Hospital das Clínicas de Goiânia. Rev Dor. 2009;10(3):231-5.

19. Posso MB, Giaretta VM, Santanna AL, Ranzani RC, Gouvea AL. [Nurses' perception of the management of chronic non-malignant pain with opioids]. Rev Dor. 2013;14(1):7-11. Portuguese.

20. Cunha AA. [Analgesia and anesthesia during labour and delivery]. Femina. 2010;38(11):599-06. Portuguese.

21. Soares EC, Lucena MR, Ribeiro RC, Rocha LL, Vilas Boas WW. [Remifentanil as analgesia for labor]. Rev Bras Anestesiol. 2010;60(3):340-46. Portuguese.

22. Baraldi AC, Almeida AM, Panobianco MS, Mamede FV. [The use of obstetric epidural analgesia: a metanalysis]. Rev Enferm UERJ. 2007;15(1):64-71. Portuguese.

23. de Souza PM, Murad K, Gonçalves ATS, Veleda NF, Corrêa R, Oliveira AC, et al. Comparativo de efetividade da meperidina e morfina: utilizaçấo no pós-parto. In: Souza PM, Araujo BG, Silva LP. Farmacologia Clínica: textos informativos. Brasília; 2012. 38-40p

24. de Souza PM, Murad K, Gonçalves ATS, Veleda NF, Corrêa R, Oliveira AC, et al. Analgesia no pós-parto. In: Souza PM, Araujo BG, Silva LP. Farmacologia Clínica: textos informativos. Brasília; 2012. 33-7p.

25. Comare. Parecer de Exclusão da Comissão Técnica e Multidisciplinar de Atualização da Relação Nacional de Medicamentos Essenciais - Relação Nacional de Medicamentos Essenciais. Rename: Ed. Brasília; 2006. 1p.

26. Ribeiro S, Schmidt AP, Schmidt SR. [Opioids for treating non malignant chronic pain: the role of methadone]. Rev Bras Anestesiol. 2002;52(5):644-51. Portuguese.

27. Mencía SB, López-Herce JC, Freddi N. [Analgesia and sedation in children: practical approach for the most frequent situations]. J Pediatr. 2007;83(Suppl2):S71-82. Portuguese.

28. Rang HP, Dale MM, Ritter JM, Flower RJ. Farmacologia. 6a ed. Rio de Janeiro: Elsevier; 2007. 829p.

29. Vaughan CW, Connor M. In search of a role for the morphine metabolite morphine-3-glucuronide. Anesth Analg. 2003;97(2):311-2.

30. Raffa RB. Analgesic, antipyretic and anti-inflammatory drugs. In: Remington JP. The science and practice of pharmacy. $21^{\text {st }}$ ed. Philadelphia (USA): Lippincott Williams \& Wilkins; 2006. 1524-42p.

31. COREN. Conselho Regional de Enfermagem de São Paulo - Parecer COREN-SP PRCI 99066/2012: Realizaçăo pelo enfermeiro de procedimento de recarga de bomba de morfina implantável. 2012.

32. Plummer JL, Owen H, Ilsley AH, Inglis S. Morphine patient-controlled analgesia is superior to meperidine patient-controlled analgesia for postoperative pain. Anesth Analg. 1997;84(4):794-9.

33. Kraychete DC, Sakata RK. [Use and rotation of opioids in chronic non-oncologic pain]. Rev Bras Anestesiol. 2012;62(4):558-62. Portuguese.

34. Bańo MD, López ML, Agujetas M, Muńoz V, Guillén JL. De la metadona al LAAM: Nuevos perfiles terapéuticos. Utilidad de la monitorización terapéutica (MT). Adicciones. 2001;13(3):305-14.

35. Salamonde GL, Verçosa N, Barrucand L, Costa AF. [Clinical and therapeutic analysis of oncology patients treated at the pain and palliative care program of the Hospital Universitário Clementino Fraga Filho in 2003]. Rev Bras Anestesiol. 2006;56(6):60218. Portuguese. 5 